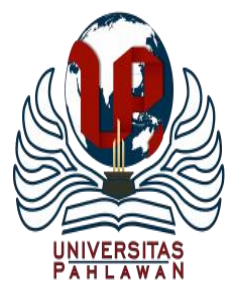

Jurnal Abdidas Volume 1 Nomor 5 Tahun 2020 Halaman 467 - 470

JURNAL ABDIDAS

http://abdidas.org/index.php/abdidas

\title{
Sosialisasi Controling Ilegal Fishing sebagai Upaya Peningkatan Pemberdayaan Potensi Masyarakat di Desa Dudewulo
}

\author{
Yusni Pakaya ${ }^{1}$, Nopiana Mozin ${ }^{2}$ \\ Fakultas Ilmu Sosial, Universitas Negeri Gorontalo, Gorontalo, INdonesia ${ }^{1,2}$ \\ E-mail : yusnipakaya@ung.ac.id ${ }^{1}$, nopianamozin@ ung.ac.id ${ }^{2}$
}

\begin{abstract}
Abstrak
Penangkapan ikan secara ilegal sudah menjadi fenomena yang tak luput dari pengamatan pemerintah. Jangan heran banyak kasus-kasus penangkapan ikan secara ilegal tanpa izin dengan menggunakan bom yang menyebabkan rusaknya ekosistem laut. Penangkapan ikan dengan menggunakan bom ini dianggap lumrah bagi sebagian besar masyarakat nelayan di Popayato, padahal hal ini termasuk dalam kejahatan illegal fishing. Sasaran pengabdian ini adalah masyarakat nelayan Desa Dudewulo, Kabupaten Pohuwato. Pengabdian masyarakat ini bertujuan untuk memberikan pemahaman kepada masyarakat tentang upaya pencegahan penangkapan ikan secara illegal melalui program controlling illegal fishing. Metode pelaksanaan kegiatan ini adalah sosialisasi dan tanya jawab, serta pembuatan struktur organisasi pengurus controlling illegal fishing. Selain itu pengabdian pada masyarakat ini merupakan suatu rujukan bagi pemerintah daerah setempat untuk mencegah adanya penangkapan ikan secara illegal.
\end{abstract}

Kata kunci : sosialisasi, illegal fishing, controlling ilegal fishing

\section{Abstract}

Illegal fishing has become a phenomenon that cannot escape the government's observation. It is not surprising that there are many cases of illegal fishing without a permit using bombs that cause damage to the marine ecosystem. Catching fish using this bomb in a common environment for most of the fishing community in Popayato, even though this is included in the crime of illegal fishing. The target of this service is the fishing community of Dudewulo village, Pohuwato Regency. This Community Service aims to provide understanding to the community about efforts to prevent illegal fish through programs that control illegal fishing. The method of implementing this activity is socialization and question and answer. As well as creating a management organizational structure that controls illegal fishing. In addition, this community service is a reference for the local government to prevent illegal fishing.

Keywords: socialization, illegal fishing, illegal fishing control

Copyright (c) 2020 Yusni Pakaya, Nopiana Mozin

$\triangle$ Corresponding author

Address : Universitas Negeri Gorontalo

ISSN 2721- 9224 (Media Cetak)

Email : nopianamozin@ung.a.c.id

ISSN 2721- 9216 (Media Online)

Phone : 085240646804

DOI : https://doi.org/10.31004/abdidas.v1i5.100 


\section{PENDAHULUAN}

Maraknya penggunaan bom untuk menangkap ikan kian banyak terjadi, hal ini malah dianggap lumrah oleh sebagian masyarakat, sehingga mereka lupa bahkan tidak tahu bahwa sebenarnya hal itu bertentangan dengan hukum. Penangkapan ikan dengan menggunakan bom ini adalah salah satu kejahatan illegal fishing. Illegal fishing merupakan kegiatan menangkap ikan yang dilakukan secara ilegal atau bertentangan dengan aturan yang ada (Mahmudah, 2015).

Penangkapan ikan secara ilegal menurut Undang-undang Perikanan merupakan salah satu pencurian ikan, yang berbahaya dan beresiko merusak ekosistem laut karena biasanya menggunakan bahan peledak (bom ikan) dan jelas hal ini dilakukan tanpa di dasari adanya Surat Izin Penangkpan Ikan (SIPI) bahkan mereka hanya mengguanakan SIPI palsu (Fernandes, 2017). Penangkapan ikan secara illegal ini umumnya banyak terjadi di Indonesia karena letaknya berada di antara dua benua. Praktik illegal fishing inipun biasanya menggunakan alat tangkap terlarang serta melakukan penangkapan ikan yang diluar daerah yang tidak diizinkan (Naim, 2010).

Pengabdian masyarkat ini bertujuan untuk meningkatkan pemahaman nelayan Desa Dudewulo Kabupaten Pohuwato dalam melakukan penangkapan ikan yang sesuai dengan standar aturan yang ada, sebagai upaya pencegahan penangkapan ikan secara ilegal.

\section{METODE}

Metode yang dilakukan dalam kegiatan pengabdian masyarakat ini yaitu sosialisasi yang ditujukan untuk memberikan pengetahuan kepada masyarakat tentang illegal fishing, serta bagaimana melakukan penangkapan ikan sesuai aturan perikanan yang telah ada. Dalam kegiatan ini kami juga bekerja sama dengan pemerintah desa setempat dalam pembentukan struktur organisasi pengurus controlling illegal fishing di Desa Dudewulo Kabupaten Pohuwato.

\section{HASIL DAN PEMBAHASAN}

Kegiatan pengabmas Fakultas Ilmu Sosial Universitas Negeri Gorontalo ini menghasilkan kerja sama yakni Program Controling Ilegal Fishing yang dalam hal ini berupa Penerbitan Surat Keputusan tentang struktur organisasi Pengurus Controling illegal fishing oleh Pemerintah Desa Dudewulo Kabupaten Pohuwato.

Sebelum dilaksanakan pengabdian masyarakat ini, Desa Dudewulo sebelumnya belum memiliki struktur organisasi pengurus controlling illegal fishing, sehingga kami mencoba untuk melakukan sosialisasi terlebih dahulu tentang apa dan bagaimanakah sebenarnya illegal fishing tersebut. Pada kegiatan sosialisasi dilakukan tanya jawab terkait penangkapan ikan secara illegal, sehingga masyarakat nelayan di desa Dudewulo paham tentang bagaimana melakukan penangkapan ikan secara legal dan sesuai standar aturan yang ada.

Kegiatan sosialisasi dilaksanakan pada tanggal 20 september 2020 dibantu oleh mahasiswa KKN Tematik Universitas Negeri Gorontalo dan di hadiri oleh narasumber hukum yang ahli dibidangnya serta menghadirkan 
pemerintah desa setempat dan masyarakat nelayan Desa Dudewulo.

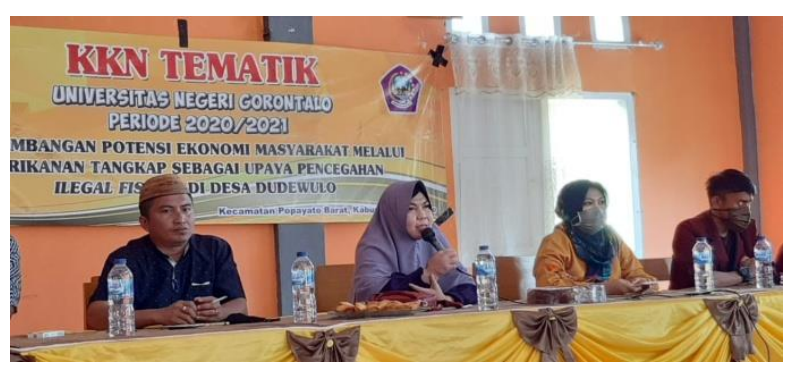

Gambar 1. Kegiatan Pengabdian

Penangkapan ikan dengan mengguakan bom ini sendiri dianggap akan sangat merugikan masyarakat itu sendiri yang nantinya menggantungkan hidup dan pencahariannya dilaut sebab hal ini jelas akan merusak ekosistem laut yang ada.

Program controlling illegal fishing ini merupakan suatu kegiatan pengawasan guna mengontrol pelaku penangkapan ikan menggunakan bom sebagai upaya untuk mencegah illegal fishing di Desa Dudewulo Kabupaten Popayato.

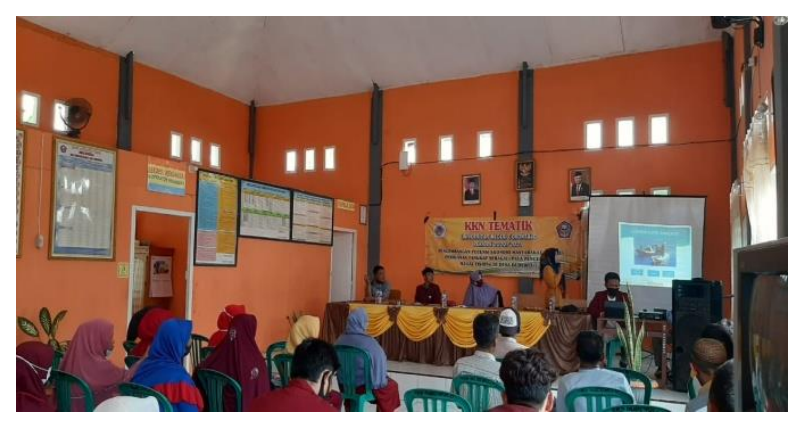

Gambar 2. Sosialisasi Controling Ilegal Fishing

Illegal fishing akan terus berlanjut jika tidak ada kesadaran dalam hal untuk melestarikan dan menjaga ekosistem laut. Jika hal ini dibiarkan nantinya generasi berikutnya tidak akan lagi bisa menikmati kekayaan dari sumber daya laut Indonesia. Laut Indonesia memiliki potensi yang besar untuk dikembangkan, akan sangat rugi jika praktek illegal fishing ini terus dibiarkan terjadi. Bagaimanapun, menjaga dan melestarikan potensi laut sangtlah penting oleh sebab itu dibutuhkan kesadaran dan kerja sama untuk mewujudkannya.

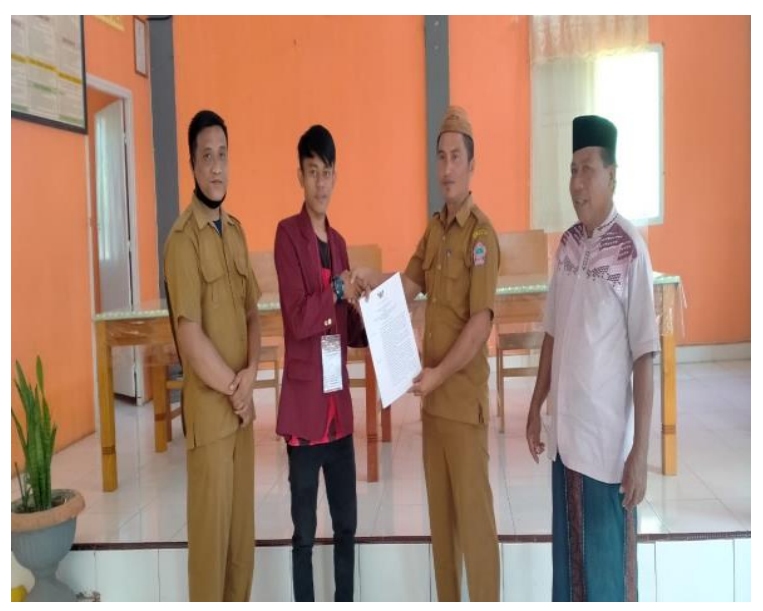

Gambar 3. Penyerahan SK Pengurus Controling Ilegal Fishing

\section{SIMPULAN}

Berdasarkan hasil pelaksanan kegiatan pengabdian masyarakat yang telah dilakukan, maka dapat disimpulkan bahwa kegiatan pengabdian masyarakat untuk sosialisasi controling illegal fishing sebagai upaya peningkatan pemberdayaan potensi masyarakat di Desa Dudewulo dapat dilaksanakan sesuai dengan apa yang diharapkan. Para mahasiswa KKN Tematik Universitas Negeri Gorontalo dan Pemerintah Desa Dudewulo maupun peserta dari masyarakat nelayan setempat berapartisipasi aktif dalam kegiatan sosialisasi, mulai dari acara pembukaan, penyajian materi tentang illegal fishing, sampai dengan kegiatan terakhir terkait pembentukan struktur organisasi pengurus 
program controling illegal fishing. Mengingat maraknya praktik illegal fishing, maka dari itu masyarakat diberikan pemahaman tentang bagaimana tata cara penangkapan ikan sesuai aturan yang ada.

\section{UCAPAN TERIMA KASIH}

Pelaksanaan kegiatan pengabdian kepada masyarakat ini, tidak lepas dari bantuan, dukungan dan bimbingan dari berbagai pihak, sehingga pada kesempatan ini kami ingin mengucapkan terima kasih kepada Lembaga Penelitian Pengabdian Masyarakat Universitas Negeri Gorontalo yang telah memberikan berupa dana hibah pengabdian kepada kami, Pemerintah Desa Dudewulo bersama masyarkat yang telah membantu dalam pelaksanaan kegiatan ini.

\section{DAFTAR PUSTAKA}

Fernandes, I. (2017). Tinjauan Yuridis Illegal Fishing di Indonesia Berdasarkan UndangUndang Perikanan. Jurnal Hukum Respublica, Riau

Mahmudah, N. (2015). Illegal Fishing Pertanggung Jawaban Pidana Korporasi di Wilayah Perairan Indonesia, Jakarta, Sinar Grafika.

Naim, A. (2010). Pengawasan Sumberdaya Perikanan Dalam Penanganan Illegal Fishing Di Perairan Provinsi Maluku Utara. Jurnal Ilmiah agribisnis dan Perikanan, Ternate.

Undang-UndangNomor 45 Tahun 2009 Perubahan Atas Undang-UndangNomor 31 tahun 2004 Tentang Perikanan 